\title{
SUSTRACCIÓN INTERNACIONAL DE MENORES EXTRACOMUNITARIA: A VUELTAS CON LA OBLIGACIÓN DE RESTITUCIÓN AUTOMÁTICA DEL CONVENIO DE LA HAYA DE 1980 EN LA PRÁCTICA ESPAÑOLA
}

\author{
EXTRA-COMMUNITY INTERNATIONAL MINOR \\ ABDUCTION: ISSUES REGARDING THE OBLIGATION \\ OF THE PROMPT RETURN OF CHILDREN FROM THE 1980 \\ HAGUE CONVENTION IN SPANISH PRACTICE
}

\author{
Clara Isabel Cordero Álvarez \\ Profesor contratado Doctor en Derecho internacional privado \\ Facultad de Derecho de la Universidad Complutense de Madrid (UCM)
}

Recibido: 09.11.2020 / Aceptado: 24.11.2020

DOI: https://doi.org/10.20318/cdt.2021.5955

\begin{abstract}
Resumen: Los supuestos de sustracción de menores que terminan conociéndose por la jurisdicción nacional, por ser España el país de destino o retención del menor, impone la adecuada interpretación de las obligaciones internacionales asumidas por nuestro Estado en este ámbito. El instrumento fundamental ante un caso de retención o traslado ilícito desde un país extracomunitario es el Convenio de la Haya de 1980. Este texto internacional obliga a los Estados contratantes a restituir de forma automática al menor que haya sido trasladado o retenido ilícitamente en su territorio si no ha transcurrido más de un año desde que se produjo la sustracción. Esta regla general cuenta con una excepción importante que permite la restitución aun pasado ese plazo, salvo que el menor se encuentre integrado en el nuevo Estado. El cómputo del plazo que rige la regla general plantea en la práctica distintas cuestiones interpretativas no uniformizadas para los Estados contratantes, lo que condiciona el resultado. La aplicación de las medidas -procesales- nacionales necesarias para llevar a cabo el proceso de restitución indicado en el Convenio, no deberían incidir per se en ese plazo para fundamentar resoluciones de denegación de la restitución, como parece que ocurre en la práctica jurisprudencial nacional bajo el paraguas del interés superior del menor, so peligro de contravenir los fines últimos del instrumento internacional.

Palabras clave: sustracción internacional de menores, Convenio de la Haya de 1980, procedimiento de restitución, restitución inmediata, excepciones, interés superior del menor, residencia habitual, integración.
\end{abstract}

\begin{abstract}
In cases of child abduction that the Spanish courts must resolve as the country of destination of the minor, the correct interpretation of the international obligations assumed by our State in this area is required. The fundamental instrument in a case of international child abduction from a nonEU country is the 1980 Hague Convention. This convention obliges all contracting States to order the return of the child forthwith -who has been illegally transferred or detained in their territory- if no more than one year has elapsed since the wrongful removal or retention took place. This general rule -the main one- has a significant exception that allows order the return of the child even after that period unless the minor is now settled in its new environment. In practice, the computation of the term regulated by the general rule raises different non-standardized interpretive issues for the Contracting States, what conditions the result of the restitution process. The application of the national - procedural - measures
\end{abstract}


regulated to comply with the Convention's provisions, should not affect, by itself, that term to base decisions on the refusal of restitution, as seems to be the national case law approach using principle of the best interests of child. Other considerations may carry the risk of contravening the purposes of the international instrument.

Keywords: international minor abduction, 1980 Hague Convention, restitution process, prompt return, exceptions, the best interest of the child; habitual resistance, integration.

Sumario: I. Introducción. II. Régimen jurídico internacional de la sustracción internacional de menores extracomunitaria: el Convenio de la Haya de 1980. 1. Características del instrumento; 2. La existencia de traslado o retención transfronterizo ilícito; 3. Restitución automática del menor y excepciones legales: el plazo de un año como factor determinante; 4 . El interés superior del menor como criterio corrector. III. Conclusiones: el Convenio de la Haya como una asignatura pendiente en la práctica nacional.

\section{Introducción}

1. En el presente trabajo se trata de abordar, esencialmente, si la interpretación y aplicación que los tribunales españoles realizan de las obligaciones internacionales asumidas por nuestro Estado, ante supuestos de sustracción de menores extracomunitarios, resulta adecuada a la luz de los instrumentos aplicables. Principalmente, el análisis se centrará en relación con el cumplimiento de la obligación del retorno automático del menor al Estado de origen -y sus excepciones- establecido en el Convenio sobre los aspectos civiles de la sustracción internacional de menores, hecho en La Haya el 25 de octubre de 1980 (en adelante, Convenio de La Haya de 1980) ${ }^{1}$, como instrumento fundamental en este ámbito fuera de la Unión Europea, de conformidad con el objeto y fines de esta norma internacional. Conjuntamente, en España, estos procedimientos deben tramitarse de conformidad con lo establecido en el Capítulo IV bis de la Ley de enjuiciamiento civil 1/2000 (LEC), bajo la rúbrica "Medidas relativas a la restitución o retorno de menores en supuestos de sustracción internacional" (artículos 778 quarter, quinquies y sexies) ${ }^{2}$. Particular análisis merece en este contexto la aplicación jurisprudencial de la excepción a la regla general de la devolución automática del menor al Estado contratante de origen (de residencia antes de que se verificara el traslado o retención ilícita a España) del segundo párrafo del artículo 12 del Convenio, que permite la restitución aun pasado ese plazo, salvo que el menor se encuentre integrado en el nuevo Estado.

A los efectos de realizar el examen de las cuestiones objeto de estudio, se va a tomar como referencia y punto de partida el pronunciamiento de la Audiencia Provincial de Valencia de 29 de junio de $2020^{3}$, relativo a una sustracción internacional incluida en el ámbito de aplicación del Convenio de la Haya de 1980. El cómputo del plazo plantea en la práctica distintas cuestiones interpretativas no uniformizadas para los Estados contratantes, lo que condiciona el resultado, como muestra la resolución que sirve de base para el análisis de esta cuestión en el presente trabajo. También se centrará el estudio en cómo incide en la práctica jurisprudencial nacional el principio del interés superior del menor como criterio correctivo de las disposiciones del texto convencional, pudiendo contravenir los fines y objeto de la norma en este sentido.

2. Tradicionalmente, los supuestos de traslado o retención de menores se constatan respecto de la prole de parejas o matrimonios de distinta nacionalidad (mixtas). No obstante, a estos supuestos han de adicionarse aquellos en los progenitores tienen residencia en distintos Estados (siendo de la misma nacionalidad), lo que incorpora un factor más en la ecuación que puede ser determinante para decidir sobre

\footnotetext{
${ }^{1}$ Instrumento de Ratificación del Convenio sobre los aspectos civiles de la sustracción internacional de menores, hecho en La Haya el 25 de octubre de 1980. BOE» núm. 202, de 24 de agosto de 1987.

${ }^{2}$ Capítulo introducido por la Disposición Final tercera, párrafo 10, de la Ley 15/2015 de Jurisdicción Voluntaria (BOE, núm. 158, de 3 de julio de 2015, con corrección de errores en BOE, núm. 210, de 2 de septiembre de 2015), en adelante LJV.

${ }^{3}$ SAP de Valencia de 29 de junio de 2020, ECLI:ES:APV:2020:1719.
} 
el traslado del menor: el centro de intereses personales de los integrantes de la pareja ${ }^{4}$; y es precisamente este último caso en el que encajaría el supuesto de hecho que se resuelve por la sentencia objeto de estudio en el que todos los interesados son de nacionalidad argentina. En este contexto, el cambio de residencia del menor no siempre obedece a un traslado ilícito, sino que hay cambios de residencia por motivos profesionales o personales que plantean la necesidad de que el niño también cambie su residencia 5 .

Ahora bien, típicamente el traslado internacional del menor ${ }^{6}$ obedece a la intención del progenitor de conseguir la aplicación de las normas de Derecho internacional privado más favorables para sus intereses (respecto del fondo del asunto: atribución y/o ejercicio del derecho de custodia/régimen de visitas), lo que se determina en función del tribunal del foro -el de traslado o retención del menor- ${ }^{7} \mathrm{Re}-$ sulta, por tanto, esencial determinar si tiene tal adjetivación el traslado del menor -ilícito-, a los efectos de aplicar los instrumentos internacionales articulados para garantizar el retorno del menor al Estado de origen. De esta suerte, es fundamental localizar el marco regulador aplicable por los tribunales nacionales para establecer si concurren o no las condiciones necesarias de aplicación y, consecuentemente, para que se desplieguen sus efectos. En este sentido, se analizará el marco regulador aplicable por los tribunales españoles ante supuestos de sustracción internacional de menores que provienen de países no comunitario (fuera de la Unión Europea), utilizando como referencia el supuesto de hecho de la sentencia analizada, esto es, cuando el traslado del menor a España se realiza desde Argentina.

Comenzaremos por indicar los antecedentes de hecho y la decisión de instancia en el asunto de referencia para poder contextualizar el objeto de estudio, para posteriormente analizar el ámbito de aplicación del Convenio de la Haya de 1980 y verificar si las obligaciones derivadas de este instrumento se cumplen por dicha sentencia.

3. Con fecha diecinueve de noviembre de 2019 , el juzgado de primera instancia ${ }^{\circ} 24$ de Valencia dicta sentencia por la que, estimada la demanda de restitución interpuesta por el Abogado del Estado -en la representación que ostenta del Ministerio de Justicia, en su calidad de Autoridad Central para la defensa del Convenio de la Haya de 1980-, declara que la retención del menor, de nacionalidad argentina, por parte de su progenitora, también de nacionalidad argentina, es ilícita de conformidad con el artículo 3 del Convenio. Consecuentemente, por dicha resolución se acuerda el retorno del menor a Argentina como Estado de residencia y su restitución al padre, para que pudiera ejercer sus potestades de custodia (con expresa condena en costas a la madre, así como la imposición a la misma de los gastos de retorno). La sentencia fundamentó su fallo en el interés superior del menor de conformidad con el Convenio Internacional de la Haya y también, sin que resulte de aplicación al caso de referencia por ser un supuesto externo a la Unión Europea, con el denominado Reglamento Bruselas II bis ${ }^{8}$.

\footnotetext{
${ }^{4}$ Una contextualización de esta problemática transnacional, un análisis de los factores de riesgo pude verse en D. CARRIzo Aguado, "Particularidades acerca de la autoridad judicial competente en supuestos de sustracción ilícita de menores en aras del Reglamento (CE) 2201/ 2003”, CDT, (Octubre 2020), Vol. 12, № 2, pp. 267-282, en particular, pp. 267-269.

${ }_{5}^{5}$ En este sentido, S. Álvarez GonzÁlez, "Traslado ilícito de menores, competencia judicial internacional y orden público", La Ley Unión Europea, $\mathrm{n}^{\circ}$ 33, 2016 (versión online)

${ }^{6}$ La sustracción internacional de menores es un tema que ha sido tratado extensamente por la doctrina, entre otros, vid. Vid. S. Álvarez GonzÁlez, "Desplazamiento internacional de menores, procedimiento de retorno y tutela judicial efectiva", Derecho Privado y Constitución, $\mathrm{n}^{\circ}$ 16, 2002, pp. 41-63; P. JIMÉNEZ BLANCO, Litigios sobre la custodia y sustracción internacional de menores, Marcial Pons, Oviedo, 2008, en esp. pp. 27-101; J.M. De La Rosa Cortina, Sustracción parental de menores. Aspectos civiles, penales, procesales e internacionales, Tirant lo Blanch, Valencia, 2010, en esp. pp. 61-273; I. ReIG FABADO, "El retorno inmediato del menor en la sustracción internacional de menores", en Revista Boliviana de Derecho, no 20, 2015, pp. 242-263; C. AzCÁrRaga Monzonís, "Sustracción internacional de menores: vías de actuación en el marco jurídico vigente", Revista Boliviana de Derecho, $\mathrm{n}^{\circ}$ 20, 2015, pp. 192-21; A. MONGE FERNÁNDEZ (Dir.), La sustracción internacional de menores desde una perspectiva multidisciplinar, Bosch Editor, Barcelona, 2019.

${ }^{7}$ De esta forma, se trata de conseguir por la vía de hecho los resultados buscados en relación con la guarda y custodia de los menores que en el Estado de origen no se ha podido conseguir o no pudieran alcanzar por la vía legal. Sobre la práctica iusprivatista del fenómeno de la sustracción internacional véase I. LORENTE MARTínEZ, Sustracción internacional de menores. Estudio jurisprudencial, práctico y crítico, Dykinson, Madrid, 2019.

${ }^{8}$ Reglamento (CE) No 2201/2003 del Consejo de 27 de noviembre de 2003 relativo a la competencia, el reconocimiento y la ejecución de resoluciones judiciales en materia matrimonial y de responsabilidad parental (en adelante, Reglamento Bruselas II bis). DO L 338 de 23.12.2003, p. 1.
} 
Para hacer efectiva la orden de retorno del menor al Estado de procedencia (Argentina), la sentencia de instancia remite erróneamente a la Autoridad central a lo dispuesto en el artículo 778.13 de la LEC para su ejecución -siendo la referencia correcta el art. 778 quinquies número $13^{9}$-.

4. Contra la sentencia de instancia se formuló recurso de apelación por parte de la demandada (la madre) ante la Audiencia Provincial de Valencia. El recurso de Apelación formulado por la progenitora demandada se fundamentó, principalmente, en alegaciones sobre error en la valoración de la prueba, en la medida que se contaba con una autorización para viajar a España firmada por el padre del menor que a su entender no se había tenido en cuenta, al igual que las numerosas comunicaciones del solicitante con su hijo; también en la indebida denegación de la prueba de exploración del menor solicitada en primera instancia (lo que se presume que se fundamentaría en el art. 778 quinquies número 8 LEC pero nada se dice al respecto). Asimismo, se exponía que el menor se encontraba plenamente integrado en Valencia, por lo que debía denegarse el retorno.

5. La parte demandante, la Abogacía del Estado, y el Ministerio Fiscal se opusieron al recurso interpuesto, solicitando la confirmación de la resolución recurrida. La Audiencia Provincial de Valencia, tras la deliberación -telemática-, votación y fallo del recurso, sin celebración de vista (al no haberse considerado necesaria ésta ni haberse practicado prueba en segunda instancia, esto es, solo valorando lo practicado por el tribunal $a d q u o^{10}$ ), dicta sentencia de fecha 29 de junio estimando el recurso formulado. En consecuencia, se revoca la sentencia dictada en primera instancia, acordando en su lugar la desestimación de la demanda de restitución del menor formulada por la representación de la Autoridad central española, denegando la restitución del menor a Argentina. La Audiencia Provincial de Valencia fundamenta su fallo, para justificar la denegación de la restitución, en una interpretación de las disposiciones del texto convencional que no parece adecuada al propio espíritu del Convenio y objetivo principal, como se expondrá a continuación siendo éste el objeto del presente trabajo.

\section{Régimen jurídico internacional de la sustracción internacional de menores extracomunitaria: el Convenio de la Haya de 1980.}

6. En este trabajo nos vamos a centrar exclusivamente en el marco regulatorio referente al procedimiento de restitución y tramitación de la orden de retorno de menores en caso de sustracción internacional en España, como Estado al que el menor ha sido trasladado o retenido ${ }^{11}$, cuando el país de origen se encuentra fuera de la Unión Europea -esto es, en supuestos extracomunitarios-, al ser este el caso en el asunto de referencia en el que el Estado de origen del menor es Argentina.

El régimen jurídico internacional en la reglamentación de los aspectos civiles de la sustracción internacional fuera de la $\mathrm{UE}^{12}$ (esto es, procedimiento de restitución, condiciones, requisitos y en su caso las causas de denegación de devolución de los menores), tiene como pieza fundamental el ya referido

\footnotetext{
${ }^{9}$ Artículo 778 quinquies. Procedimiento. 13: "En la ejecución de la sentencia en la que se acuerde la restitución del menor o su retorno al Estado de procedencia, la Autoridad Central prestará la necesaria asistencia al Juzgado para garantizar que se realice sin peligro, adoptando en cada caso las medidas administrativas precisas".

${ }^{10} \mathrm{Si}$ bien, se solicito por la Audiencia informe del Gabinete Psicosocial adscrito a los Juzgados de Familia de Valencia, acerca del grado de integración del menor, recabando por escrito el parecer de las partes.

${ }^{11}$ Desde la perspectiva procesal nacional, tanto la restitución como el retorno son actuaciones que pueden realizarse individualmente tras el proceso de sustracción -incoado mediante demanda de restitución-; ello sin perjuicio o con independencia de la probable complementariedad de ambas actuaciones en un momento posterior. $C f$. S. CALAZA LÓPEZ, "El nuevo régimen jurídico de la sustracción internacional de menores", Diario La Ley, nº 8564, 2015 (versión online), en comentario a las nuevas medidas relativas a la restitución o retorno de menores en los supuestos de sustracción internacional incorporadas a la LEC por la Ley de Jurisdicción Voluntaria, en aplicación de convenio internacional o disposiciones de la Unión Europea (arts. 778 quarter a sexies LEC)

${ }^{12}$ Dentro de la Unión Europea resulta de aplicación en este ámbito el Reglamento Bruselas II bis, aplicable para supuestos de sustracción intracomunitarios en los que el Estado de origen (residencia habitual del menor) y el de destino (retención/ traslado del menor) sea un Estado miembro vinculado por este instrumento (todos los Estados miembros salvo Dinamarca y el Reino Unido una vez que se verifique su salida de la Unión).
} 
Convenio de la Haya de 1980. Para la aplicación de las disposiciones contenidas en este Convenio (y cualesquiera otro que en esta materia resultara de aplicación por los tribunales nacionales ${ }^{13}$, así como de las disposiciones de la Unión Europea (como es el procedimiento previsto en el art. 11 del Reglamento Bruselas II bis $^{14}$ ) ha de recurrirse a la normas de procedimiento recogidas en el Capítulo IV bis de la LEC (arts. 778 quarter a sexies).

\section{Características del instrumento}

7. El Convenio de la Haya de 1980 es un instrumento que únicamente reglamenta el procedimiento de restitución (devolución) de menores de 16 años ${ }^{15}$-y en qué casos procede- al Estado contratante de residencia (Estado de origen) en caso de sustracción ilícita, esto es, retención o traslado del menor no consentida o autorizada (por ambos progenitores) a otro Estado contratante. Lo limitado del alcance de sus disposiciones obedece a los objetivos de este texto internacional ${ }^{16}$ de conformidad con su artículo 1: a) Garantizar la restitución inmediata de los menores trasladados o retenidos de manera ilícita en cualquier Estado Contratante; b) Velar por que los derechos de custodia y de visita vigentes en uno de los Estados Contratantes se respeten en los demás Estados Contratantes. La finalidad principal ${ }^{17}$ de esta norma internacional es garantizar la inmediata devolución del menor al Estado de su residencia habitual antes de ser trasladado ilícitamente a otro Estado parte, restitución que no implica decisión sobre el fondo de los derechos de guarda y visita, sino meramente un restablecimiento de la situación dada.

Este instrumento no regula las cuestiones de responsabilidad parental concomitantes a los supuestos de traslado o retención ilícitos de menores que típicamente son cometidos por alguno de los progenitores y que, generalmente, están litigando por la custodia/visitas de los menores ante los tribunales del Estado de origen. En este sentido, la principal premisa de la que parte el Convenio es que el debate sobre el fondo del asunto, esto es, los derechos de guarda y visita, deben sustanciarse ante las autoridades competentes del Estado en el que el menor tenía su residencia habitual antes del traslado ilícito ${ }^{18}$. Y la razón de ser de esta aproximación es que la residencia habitual ${ }^{19}$ del menor es el eje gravitatorio en materia de familia/menores, dado que en la generalidad de sistemas decide la competencia judicial

${ }^{13}$ Como sería el Convenio de Luxemburgo de 1980 (Convenio Europeo relativo al reconocimiento y la ejecución de decisiones en materia de custodia de menores, así como al restablecimiento de dicha custodia, hecho en Luxemburgo el 20 de mayo de 1980. Instrumento de ratificación de 9 de mayo de 1984. BOE» núm. 210, 1.09.1984, pp. 25291 a 25295) o el Convenio entre el Reino de España y el Reino de Marruecos sobre asistencia judicial, reconocimiento y ejecución de resoluciones judiciales en materia de derecho de custodia y derecho de visita y devolución de menores, firmado en Madrid el 30 de mayo de 1997 (aplicación provisional desde 30.05.1997. BOE» núm. 150, 24.06.1997, pp. 19348 a 19351; entrada en vigor 1 de Julio de 1999).

${ }^{14}$ Vid. J. R. LiéBAna OrTiz, "El nuevo proceso relativo a la sustracción internacional de menores", Revista electrónica del Departamento de Derecho de la Universidad de La Rioja (REDUR), nº 13, 2015, pp. 83-109.

${ }^{15}$ De conformidad con el art. 4, que establece este límite temporal para determinar el ámbito de aplicación del instrumento (menores de hasta los 16 años). Este límite de edad no tiene reflejo en el procedimiento del art. 11 del Reglamento Bruselas II bis, que solo indica la condición de menor (por lo que deberá ser integrado por la normas de conflicto del Estado del foro). Si bien, hay otros convenios que recurren igualmente a este límite de edad, como es el caso del referido Convenio bilateral entre España y Marruecos de 1997, que se aplicará a todo menor de dieciséis años no emancipado que posea la nacionalidad de uno de los dos Estados firmantes (art. 2).

${ }^{16}$ Un análisis pormenorizado de este Convenio, en particular respecto de sus objetivos, características y relación con otros instrumentos, E. Pérez Vera, "Informe explicativo del Convenio de la Haya de 25 de octubre de 1980 sobre Aspectos Civiles de la Sustracción Internacional de Menores", Publicaciones de la HCCH, 1982 (disponible online en https://assets.hcch.net/ docs/43df3dd9-a2d5-406f-8fdc-80bc423cdd79.pdf, última visita 21.10.2020).

${ }^{17}$ La finalidad del Convenio de la Haya de 1980 no es otra que proteger unos derechos concretos y efectivos, no teóricos o ilusorios respecto a la vida familiar entre progenitores e hijos. En este sentido, la STEDH de 13 de mayo de 1980 Asunto Artico v. Italia, $\left(\mathrm{n}^{\mathrm{o}} .6694 / 74\right), \S 33$.

${ }^{18}$ Vid. F.J. ForCada Miranda, "La creciente complejidad del Derecho internacional de Familia", Familia y sucesiones: cuaderno jurídico, $\mathrm{N}^{\circ}$. 106, 2014, pp. 15-22, en esp. pp. 18-19.

${ }^{19}$ Sobre la relevancia de este criterio de conexión en Europa puede verse, A-L. Calvo CARAVACA, "El Derecho internacional privado de la Unión Europea. Valores y principios regulativos", Cadernos do Programa de Pós-Graduação em Direito PPGDir./ UFRGS, Vol. XV, núm. 1, 2020, pp. 5.37, en esp. pp. 22-23. 
internacional, además del carácter lícito o ilícito del traslado o la retención ${ }^{20} \mathrm{y}$, en última instancia -en función de su delimitación o en su caso modificación-, condiciona el retorno del menor ${ }^{21}$.

Consecuentemente, el convenio no recoge normas de Derecho internacional privado, por lo que se necesita de otros instrumentos en materia de responsabilidad parental para determinar la competencia judicial para conocer de acciones sobre estas cuestiones -típicamente vinculadas a los supuestos de sustracción-. Entre estos instrumentos se encuentran el Reglamento Bruselas II bis entre los Estados miembros (con las excepciones de Dinamarca y Reino Unido tras su salida de la Unión) o el Convenio de la Haya de $1996^{22}$ entre Estados miembros firmantes ${ }^{23}$ y Estados parte de este instrumento ${ }^{24}$; este último instrumento resulta también determinante para localizar la ley aplicable a las acciones ejercitadas en materia de responsabilidad parental -y medidas de protección de menores- para los Estados firmantes. Por cuanto al reconocimiento de eventuales resoluciones judiciales por la que se establezcan los derechos de custodia y correlativo de visita para los progenitores (lo que en su caso determinaría la eventual legitimación activa y pasiva en la posible demanda de restitución del menor), también habría que acudir principalmente al Reglamento Bruselas II bis -para resoluciones entre Estados miembros vinculados- y, fuera del ámbito de aplicación espacial del instrumento europeo, al Convenio de la Haya de 1996 entre Estados firmantes; en menor medida (por su limitado ámbito de aplicación espacial y material) el Convenio de Luxemburgo de 1980 resultará de aplicación en materia de custodia entre Estados contratantes. Ahora bien, a este último respecto ha de recordarse que no es necesario que exista una previa resolución judicial que atribuya un determinado derecho de custodia o régimen de visitas para que pueda instarse procedimiento de restitución a la luz del Convenio de la Haya de 1980; en la medida que el instrumento lo que protege es el efectivo ejercicio del derecho de custodia o régimen de visitas y, consecuentemente, proteger al menor manteniendo su statu quo, lo cual puede producirse en una mera separación de hecho sin mediación de autoridad competente (tal y como se deduce del último párrafo del art. 3 del Convenio ${ }^{25}$ ).

8. Así pues, cabe concluir que el Convenio no prejuzga sobre la situación de fondo para que opere y, por tanto, se verifique la devolución del menor (o se deniegue, por ejemplo, si concurre alguna de las excepciones, como las causas tasadas del art. 13, el segundo párrafo del art. $12 \mathrm{o}$ la incidencia del orden público a través del art. 20). Esta conclusión se fundamenta en varias razones sobre la operatividad del instrumento: a) no revisa la eventual resolución judicial del Estado origen sobre responsabilidad parental (custodia/régimen visitas); b) no se condiciona la restitución del menor al reconocimiento en el Estado requerido (el de traslado/retención) de la resolución judicial del Estado origen sobre custodia/ régimen visita; y c) tampoco se condiciona la restitución del menor a que en el Estado de traslado/retención exista resolución contradictoria sobre el fondo. De esta suerte, el art. 16 establece que si se hubiera iniciado un procedimiento -aún pendiente- sobre el ejercicio de la responsabilidad parental respecto del menor trasladado en ese Estado, el tribunal no podría resolver, sino que debería suspender hasta que se falle sobre la restitución del menor (negativamente para poder seguir como nuevo Estado de residencia

\footnotetext{
${ }^{20}$ Este elemento fundamenta la demanda de restitución, pues solo prosperará si el menor tenía su residencia habitual inmediatamente antes del traslado o la retención ilícitos en el Estado donde se presenta. Cfr. I. ReIG FABADo, "La construcción del concepto autónomo de residencia habitual del menor en los supuestos de sustracción internacional de menores", CDT, vol. 11, $\mathrm{n}^{\mathrm{o}} 1,2019$, pp. 877-888, en esp. p. 887.

${ }^{21}$ Un análisis de la delimitación jurisprudencial del criterio de residencia habitual del menor, tanto del TJUE como nacional, puede verse en D. CARrizo Aguado, "Particularidades acerca de la autoridad judicial...", loc. cit., pp. 274-277. En particular, sobre la concreción de la residencia habitual del menor en los supuestos de sustracción internacional de menores, a la luz del Convenio de la Hay de 1980 y del Reglamento Bruselas II bis, véase, I. ReIG FABADO "La construcción del concepto autónomo...", loc. cit., pp. 883-885.

${ }^{22}$ Convenio relativo a la competencia, la ley aplicable, el reconocimiento, la ejecución y la cooperación en materia de responsabilidad parental y de medidas de protección de los niños, hecho en La Haya el 19 de octubre de 1996. Instrumento de ratificación por parte de España, BOE núm. 291, 02.12.2010.

${ }^{23}$ Vinculados por el convenio, tras autorización por la UE (en ejercicio de su competencia exclusiva externa del art. 3.2 TFUE) para la firma de este instrumento mediante Decisión 2003/93/CE sobre el Convenio de La Haya de 1996 relativo a las cuestiones jurídicas internacionales en materia de responsabilidad parental y de medidas de protección de los niños (DO L 48 de 21.2.2003).

${ }^{24}$ Donde se incluyen Dinamarca y, en su momento, Reino Unido tras el Brexit.

${ }^{25}$ Vid. infra apartado II.1 sobre la delimitación de los supuestos ilícitos a la luz del art. 3 del Convenio de la Haya de 1980.
} 
del menor) o haya transcurrido el plazo razonable para presentar demanda de restitución (generalmente un año de conformidad con el art. 12).

\section{La existencia de traslado o retención transfronterizo ilícito}

9. Para que la autoridad competente del Estado contratante pueda resolver sobre la devolución o no del menor, es necesario que el traslado/desplazamiento transfronterizo sea reputado como ilícito -y por tanto haya sustracción internacional-. El Juzgado de instancia de Valencia, como órgano competente para conocer del procedimiento de restitución por ser el de situación física del menor, debía decir sobre la devolución de éste a Argentina (como Estado de origen), partiendo de la premisa de que se tratara de un traslado ilícito a los efectos del art. 3 del Convenio. Típicamente, la ilicitud del traslado se identifica con la infracción de los derechos de custodia del menor reglamentados de conformidad con el ordenamiento del Estado de residencia habitual del menor ${ }^{26}$ (en el caso de referencia, Argentina), lo que ocurre en el caso objeto de estudio que resuelve la sentencia analizada.

10. El Artículo 3 del Convenio determina cuándo un traslado o retención se considera ilícito a los efectos de esta norma. Son dos los requisitos acumulativos los que se exigen a tales efectos: a) que el traslado o retención conlleve una infracción de un derecho de custodia atribuido, separada o conjuntamente, a una persona, a una institución o a cualquier otro organismo, de conformidad con el Derecho vigente en el Estado de origen - tal derecho puede resultar, bien de una atribución de pleno derecho, bien de una decisión judicial o administrativa o de un acuerdo vigente entre las partes según el Derecho de dicho Estado-; y b) que en el momento del traslado o de la retención, ese derecho de custodia se ejercía de forma efectiva, separada o conjuntamente, o se habría ejercido de no haberse producido dicho traslado o retención. En consecuencia, se requiere que exista un efectivo desplazamiento internacional del menor que lo aparte del otro progenitor (que ostenta de forma efectiva un derecho de custodia, de manera exclusiva o conjunta con el sustrayente) y que dicho desplazamiento provoque un cambio sustancial en el estatus del menor.

En el caso de referencia no existe duda de que configura un supuesto de traslado ilícito del art. 3 del Convenio, y como tal se refiere tanto la sentencia de instancia como la resolución de la Audiencia Provincial objeto de estudio -fundamentada tal conclusión en la prueba existente ${ }^{27}$. De los autos se concluye que, si bien el menor salió de Argentina con la madre conociéndolo y consintiéndolo el padre, en junio de 2019 éste revocó la autorización recíproca para viajar que los progenitores habían firmado en septiembre de 2015. Ahora bien, no consta prueba alguna de que la permanencia en España fuera conocida previamente ni aceptada por el padre del menor - de hecho, incluso constan en autos conversaciones del padre con el colegio en la que dio a entender en todo momento que el menor regresaría al mismo en Argentina-. La falta de consentimiento del padre en el traslado y cambio de residencia del menor a España se desprende de forma clara de la presentación de la solicitud de restitución, que tuvo entrada en la Autoridad Central española en fecha 4 de julio de 2019, y la posterior presentación de la demanda en sede judicial (Juzgado de primera instancia) por la Autoridad Central. Consecuentemente, estamos ante una permanencia en España del menor no consentida por el padre, cuando la madre no tenía atribuida en exclusiva el ejercicio de la patria potestad. La interpretación de los hechos probados en el asunto de referencia, para la aplicación del Convenio de la Haya de 1980, resulta en este apartado del todo correcta

\footnotetext{
${ }^{26}$ Ahora bien, el derecho de custodia no es el única figura jurídica concomitante a la sustracción internacional dado que también la filiación (que conlleva la responsabilidad parental y, por tanto, la atribución de la custodia) puede resultar determinante a los efectos de concluir si el traslado o retención son ilícitos. En este sentido puede verse C. AzCÁRraGa Monzonís / P. QuinzÁ Redondo, "Sustracción internacional de menores y Convenio de la Haya de 1980. Comentario de la sentencia de la Audiencia Provincial de Las Palmas (Sección 3ª núm. 377/2017, de 29 de junio”, CDT, vol. 10, nº 2, 2018, pp. 795- 801; en un supuesto en el que una de las cuestiones de fondo que subyace es precisamente la filiación paterna y, correlativamente, el tema de la custodia, ante un caso de traslado desde Argentina a España de un bebé estando sustanciándose en aquél país la cuestión de filiación judicialmente, solicitando favorablemente el padre procedimiento de restitución en el Estado de origen.

${ }^{27}$ Vid. FJ Cuarto.
} 
y adecuada, lo que no puede decirse del análisis posterior que de los mismos hechos se realizan para fundamentar la denegación del retorno del menor a Argentina, revocando la sentencia de instancia.

\section{Restitución automática del menor y excepciones legales: el plazo de un año como factor deter- minante}

11. El Convenio de la Haya de 1980 es un instrumento eficaz en la resolución de los conflictos vinculados a la retención o traslado ilícito de menores, por cuanto que garantiza -salvo excepciones- la restitución inmediata del menor al Estado contratante de origen en el que tiene su residencia habitual ${ }^{28}$. Junto con la regla general de restitución automática del menor a su Estado parte de residencia habitual -cuando ha sido sustraído ilícitamente-, el Convenio prevé un sistema de excepciones tasadas al retorno con el fin de respetar el principio del interés superior del menor. Estas excepciones a la devolución del menor deben interpretarse de forma restrictiva -por cuanto que desplazan a la regla general que consagra la finalidad principal del instrumento- $y$, por supuesto, acreditarse la concurrencia de los motivos de oposición a la restitución ${ }^{29}$.

12. El artículo 12 propugna la restitución automática e inmediata del menor al Estado contratante de origen, cuando el procedimiento se hubiera instado -ante autoridad judicial o administrativa- en el Estado contratante donde se encuentre el menor -ilícitamente trasladado/retenido- antes del transcurso de un año desde que se produjo el traslado retención no autorizada. Como excepción a este retorno inmediato del menor, el párrafo segundo de este precepto establece que aún en el caso de que se hubiere iniciado el procedimiento después de la expiración del plazo señalado de un año, no se denegará la restitución por la autoridad competente salvo que quede demostrado que el menor ha quedado integrado en su nuevo ambiente. El tenor literal de la disposición es claro y parece evidente que el transcurso del plazo del año referido en el primer párrafo, por sí mismo considerado, no es una causa para denegar la devolución inmediata del menor, sino que exige que se pruebe que el menor esté efectivamente integrado en su nuevo medio. El plazo de un año es, por tanto, una presunción iuris tantum en la consideración de la nueva residencia del menor, y que exige que se pruebe efectivamente que el menor está plenamente integrado en el nuevo entorno y el retorno supondría un perjuicio, por cuanto suponga un cambio sustancial en el estatus del niño. Esta excepción al plazo del año previsto respecto de la regla general -que impera la restitución inmediata del menor- no puede confundirse con las causas de denegación de la restitución que operan con independencia del cómputo del tiempo transcurrido desde que se produjo el traslado o retención ilícitos y la solicitud de la restitución, articuladas en el art. 13 de la norma convencional.

Es precisamente en la excepción del segundo párrafo del art. 12 en la que se fundamenta la sentencia de la Audiencia que se analiza para denegar la restitución del menor, revocando la sentencia de instancia. En el caso de referencia, en primera instancia la cuestión del plazo en el que fue incoado el procedimiento de restitución del menor en España (ante autoridad judicial) no fue analizada ni debatida, siendo en apelación el momento en el que por vez primera se refiere y se aborda si concurre en este asunto el requisito necesario para apreciar esta excepción del artículo 12. De hecho, la parte recurrente no hace referencia alguna esta cuestión del plazo, ni en primera instancia ni como causa para fundamentar el recurso de apelación frente a la sentencia que ordenaba la devolución del menor. Se trata de una consideración nueva por parte del juzgador ad quem (basada en hechos no correctos del supuesto) y en el que fundamenta exclusivamente su posición.

13. Desde nuestro punto de vista, el error de la Audiencia radica en el cómputo del año que realiza en el asunto de referencia; en particular, el momento de inicio de este. Según los hechos recogidos en la sentencia, el traslado del menor de Argentina a España por la madre se produjo en agosto de 2018,

\footnotetext{
${ }^{28}$ Vid. S. Álvarez GonzÁlez, "Desplazamiento internacional de menores...", loc. cit., p. 43

${ }^{29}$ En lo que respecta a la interpretación y alcance de las causas de denegación de restitución del menor como excepción a la regla general, puede verse, J.J. CASTELLó PASTOR, "Excepciones legales al retorno del menor en los supuestos de sustracción internacional", $C D T$, vol. 10, $\mathrm{n}^{\circ}$ 1, 2018, pp. 561- 567, y análisis jurisprudencial en él referido; E. RodRíGuez PINEAU, "La oposición al retorno del menor secuestrado: movimientos en Bruselas y La Haya”, REEI, nº 35, 2018.
} 
y el padre presentó solicitud de retorno ante la Autoridad central española (el Ministerio de Justicia) en julio de 2019. El término ad quem lo marca la fecha de presentación de la demanda, y el procedimiento judicial para la restitución no se incoa hasta noviembre de 2019 (sin indicar fecha concreta, ni este dato se extrae de los Autos) desde agosto de 2018, que es cuando entiende el tribunal -erróneamente- se produjo el traslado ilícito. Siendo que la fecha de sentencia de primera instancia que se recurre es de 19 de noviembre de ese año, resulta significativo que la demanda judicial se presentara en noviembre de 2019, dadas las pruebas practicadas que obran en autos (si bien, no consta que se hubiera tomado declaración al menor, de 8 años de edad, pese haberse solicitado por la madre en tiempo y forma en primera instancia, contraviniendo la obligación impuesta en este sentido en el art. 778 quinquies numeral 8 de la LEC); por lo que sí se cumple por el juzgado los plazos de urgencia consagrados en nuestra Ley rituaria para esta primera fase del procedimiento -no así en segunda instancia-. Tampoco se solicitó por el juzgado informe relativo a la integración del menor en España. Tal omisión -desde nuestro punto de vista- estaba justificada, en la medida que no habiendo transcurrido el plazo del año señalado en el primer párrafo del artículo 12 del Convenio, la devolución es automática sin tomar en consideración factor de valoración adicional -como sería la posible integración del menor en el nuevo medio-. No obstante, es la Audiencia Provincial la que recibidas la actuaciones acuerda, con carácter urgente, recabar informe del Gabinete Psicosocial acerca del grado de integración del menor $^{30}$; lo que le sirve para fundamentar su tesis de que operada la excepción del segundo párrafo del art. 12 del Convenio, probada la integración del menor en España, procedía denegar la restitución.

14. Lo determinante para saber si se verificó o no el plazo del año del primer párrafo del art. 12 es establecer cuándo se inicia el cómputo, esto es, cuál es el hecho que determina que el traslado pasa a ser ilícito y, por tanto, el progenitor vulnerado en su derecho debe instar la restitución en el periodo máximo de un año para conseguir la devolución automática -so peligro de integración del niño en el nuevo entorno-. El inicio del cómputo del año marcado por el tribunal de apelación es el simple traslado físico del menor a España en agosto de 2018, sin tener en consideración las circunstancias concretas del caso. Tal y como se indica en la propia sentencia, entre los hechos probados se encuentra que no fue hasta junio de 2019 que se produjo la revocación de la autorización recíproca para viajar firmada por ambos progenitores, esto es, cuando el padre fue consciente de la intención de la madre de trasladarse/quedarse con carácter definitivo en España. La consideración de "recíproca" de la autorización no es una cuestión baladí, pues se trataba de una autorización de ambos progenitores otorgada en 2015 para que cualquiera de ellos pudiera viajar con el menor fuera de su Estado de residencia habitual (Argentina), lo que no puede entenderse como un salvoconducto para trasladarse y establecerse definitivamente en otro país por cualquiera de los progenitores sin autorización del otro. Es, por tanto, distinto autorizar para viajar a España que consentir para establecerse definitivamente en nuestro país. Consecuentemente, es cuando se tiene conocimiento por el progenitor del traslado definitivo a España, y no el temporal (autorizado), el hecho que debe marcar "el momento" en que se produjo el traslado o retención ilícitos a los efectos del cómputo del año -precisamente cuando el padre tiene conocimiento de este carácter permanente del traslado es cuando revocó la autorización en junio de 2019 y, a continuación, procedió a solicitar la restitución ante la Autoridad Central Española, en julio de ese año-. Solo esta interpretación en el caso de referencia es compatible con los informes explicativos del texto convencional, según los cuales a los efectos del artículo 12 la concreción de la fecha decisiva en caso de retención debe ser entendida como la fecha en la que el menor hubiese tenido que ser devuelto al titular de derecho de custodia o "en la que éste negó su consentimiento a una extensión de la estancia del menor en otro lugar distinto del de su residencia habitual" ${ }^{\prime \prime}$, siendo este último el caso en el que nos encontramos.

\footnotetext{
${ }^{30}$ Y ello al amparo de un artículo del Convenio que no refiere. Deduciendo que se trata del art. 11 de la norma convencional, que se limita a indicar que en el procedimiento para la restitución de los menores en los Estados parte las autoridades deben proceder de manera urgente; lo que no se cumple, por otro lado, por parte de la Audiencia, en la medida que tarda más de siete meses en resolver sobre el recurso de apelación incumpliendo, asimismo, los plazos impuestos en el art. 778 quinquies número 11 de la LEC.

${ }^{31}$ Cfr., "Informe sobre el Convenio" de E. Pérez Vera, loc. cit., número 108.
} 
A mayor abundamiento, la Audiencia apoya a más su decisión en los casi dos años transcurridos desde traslado inicial (insistimos, consentido por su carácter temporal) hasta que se dicta sentencia resolviendo la apelación. Resulta llamativo que los efectos negativos de la dilatación del procedimiento en segunda fase (más de siete meses para dictar sentencia) se hagan recaer sobre el progenitor que insta la restitución ${ }^{32}$, refiriendo este hecho como un factor más a considerar para afirmar la integración del menor en el nuevo país y, por tanto, ratificar la decisión de no devolución ${ }^{33}$. Esta interpretación es contraria a la norma convencional, que establece que para que se pueda activar el segundo párrafo del art. $12 \mathrm{y}$, por tanto, denegar la restitución del menor con base en su integración en el nuevo medio, es preciso que haya transcurrido un período de tiempo superior a un año entre la sustracción -momento en el que el traslado temporal se vuelve definitivo y por tanto ilícito, es decir, junio de 2019- y el momento en que se presenta la solicitud de retorno del menor (en noviembre de 2019). El plazo que transcurre desde que se incoa el procedimiento de retorno ante la autoridad competente y cuando éste finalmente se resuelve no debe tomarse en consideración a estos efectos -es meridiano en este sentido el art. 12-; más aún cuando las partes puede acudir a artimañas procesales para dilatar los procedimientos a estos efectos. Así, si la solicitud de restitución del menor se presenta en un plazo inferior a un año y la autoridad competente resuelve después del transcurso del año, no cabe activar el art. 12, párrafo segundo del Convenio ${ }^{34}$.

\section{El interés superior del menor como criterio corrector.}

15. El interés prevalente del menor es el criterio interpretativo al que alude el tribunal de apelación para necesariamente tener que valorar la integración del menor en España antes de poder decidir sobre el retorno $\left(\mathrm{FJ} 5^{\circ}\right)$. A tales efectos, se relata en la sentencia los textos normativos en los que el interés del menor es consagrado como criterio fundamental para la interpretación y aplicación de sus disposiciones. Así, con carácter general, la Convención de las Naciones Unidas sobre los derechos del niño de 20 de noviembre de 1989 lo proclama al disponer que "en todas las medidas concernientes a los niños que tomen las instituciones públicas o privadas de bienestar social, los tribunales, las autoridades administrativas o los órganos legislativos, una consideración primordial a que se atenderá será el interés superior del niño" (art. 3.1). Este principio igualmente está consagrado en nuestra legislación nacional en diversos texto normativos; a saber, en distintos preceptos del Código Civil (arts. 92, 93, 95, 103.1, 154, 158 y 170), en la Ley Orgánica 1/1996 de Protección Jurídica del Menor y en cuantas normas y disposiciones regulan cuestiones matrimoniales, paterno, filiales o tutelares. Todo ello permite concluir

32 Teniendo en cuenta que la sentencia de instancia es de 19 de noviembre de 2019 y la sentencia de apelación de 29 de junio de 2020, sin que quede constancia de que hubiera procedido suspensión del procedimiento por solicitud de mediación por alguna de las partes. El resultado es que ha pasado un año y 10 meses desde que el menor abandonó el Estado de origen (inicialmente de forma autorizada), es un plazo que no es imputable al padre sino a la lentitud de la justicia española y no puede ir en detrimento de sus derechos.

${ }^{33}$ Lo que va en contra del espíritu del instrumento que predica la restitución inmediata mediante un procedimiento de urgencia (art. 11 del Convenio), con infracción además de la normativa procesal interna prevista (plazos concretos) para el cumplimiento de estas obligaciones internacionales (art. 778 quinquies de la LEC, en segunda fase en el número 11). La guía de buenas prácticas, medidas de aplicación, de la Conferencia de La Haya es meridiana en este sentido, pues ya en el año 2003 señalaba que" El procedimiento expeditivo es esencial en todas las etapas del proceso del Convenio, incluidas las apelaciones. Los Estados contratantes deberán utilizar los mejores procedimientos de urgencia disponibles para lograr los objetivos del Convenio. Casi todos los aspectos de aplicación afectarán la rapidez del trámite de las peticiones". CONFERENCIA DE LA HAYA, Guía de buenas prácticas en virtud del Convenio de La Haya del 25 de octubre de 1980 sobre los aspectos civiles de la sustracción internacional de menores, segunda parte - medidas de aplicación, Family Law, Bristol, 2003, Sección 1.5, Síntesis VII. (versión en español ISBN 0 85308 8985). No se trata de un problema único y particular de la práctica española, sino que es tristemente generalizado entre los Estados parte. En este sentido se ha pronunciado en su última reunión (la séptima) la Comisión Especial sobre el funcionamiento práctico del Convenio de 1980 sobre Sustracción Internacional de Menores y del Convenio de 1996 sobre Protección de Niños, concluyendo la necesidad de resolver el problema de las demoras en los procedimientos en virtud del Convenio de 1980 (los días 10-17 de octubre de 2017, resultado puede consultarse en https://assets.hcch. net/docs/13a63e16-fdf4-488b-9368-123c96cdcf67.pdf)

${ }^{34}$ Entre otros, vid. A. L. Calvo Caravaca / J. Carrascosa González, "Protección de menores. Sección Quinta. Sustracción internacional de menores", en A. L. Calvo Caravaca / J. Carrascosa González (Dirs.), Derecho Internacional Privado, vol. II, $18^{\mathrm{a}}$ ed., Granada, Comares, 2018, epígrafe 18. 
que el interés del menor se configura en nuestro sistema como un principio básico y orientador de la actuación judicial -lo que se corresponde con la proclamación en el art. 39.2 de la Constitución de la protección integral de los hijos ${ }^{-35}$. Ahora bien, de forma consciente la Audiencia no refiere el tratamiento de este criterio en el texto convencional cuya aplicación particular le corresponde para decidir sobre la restitución o no del menor: el Convenio de la Haya de 1980 -que razonablemente no puede tener el mismo tratamiento que la legislación de fuente interna-.

16. Todos los textos normativos que reglamentan cuestiones vinculadas con menores se configuran típicamente sobre la base de la protección o garantía del interés superior del menor, y el Convenio de la Haya de 1980 no es distinto ${ }^{36}$. Ahora bien, el alcance y efectos de este criterio debe determinarse en cada una de las normas en función de sus objetivos y cómo este principio haya sido integrado para su consecución. En el Convenio de la Haya de 1980 el interés del menor se identifica con su permanencia en su entorno vital -Estado de origen- $y$, como consecuencia, en el automático e inmediato retorno cuando es desplazado a otro Estado ${ }^{37}$. Ello conduce inevitablemente a que primero se retorna al menor y luego, en su caso, se resuelve sobre la atribución y/o ejercicio los derechos de guarda y visita ${ }^{38}$.

Resulta también relevante, a los efectos de la interpretación y aplicación de este texto internacional, y el posible alcance corrector del criterio interés del menor en su cumplimiento, el hecho de que interés superior del menor solo es referido de forma expresa en la exposición de motivos no así en su articulado. La razón de esta omisión -buscada- era evitar el peligro de que las autoridades competentes de los Estados parte recurrieran a esta figura para sortear el retorno del menor desplazado en beneficio del progenitor que realizó el desplazamiento ilegal ${ }^{39}$ - en la medida que se podría argumentar erróneamente que el objetivo convencional relativo al retorno del menor debería estar siempre subordinado a la toma en consideración de su interés-. Así pues, el interés superior del menor ha de ser evaluado en el marco estricto del análisis restrictivo de las excepciones de la regla general del art. 12 del Convenio y siempre dentro de la finalidad y objetivos del propio instrumento.

17. El hecho de que no se recoja este criterio en el contenido dispositivo de la norma convencional no se traduce en que se ignore esta realidad social, que proclama la necesidad de tener en cuenta el interés de los menores para resolver todas las cuestiones en las que estén involucrados, sino que su importancia es expresamente referida en su Preámbulo (y precisamente sobre su base se justifica la previsión de mecanismos efectivos para restituir al menor a su medio cuando se verifica un traslado o retención ilícitos). Del preámbulo del Convenio se desprende la filosofía del instrumento respecto del interés del menor, la cual se resume en que la lucha contra la multiplicación de las sustracciones internacionales de menores debe basarse siempre en la pretensión de protegerles, interpretando su verdadero interés. Siendo en este sentido el derecho del menor a no ser trasladado o retenido -en nombre de derechos más

\footnotetext{
${ }^{35}$ Lo que conduce a que toda resolución que una autoridad nacional deba adoptar y que afecte a un menor debe realizarse en atención a este principio, que nuestra legislación en materia de menores define como rector e inspirador de todas las actuaciones de los poderes públicos relacionadas con el niño, tanto administrativas como judiciales (SSTC 124/2002, de 20 de mayo, FJ 4 , y 47/2009, de febrero, FJ, 3 entre otras)» (STC 127/2013, de 3 de junio, FJ 6).

${ }^{36} \mathrm{Vid}$. A. Marín Velarde, F. Moreno Mozo, "El interés superior del menor y su relevancia en la sustracción internacional de menores", en A. MONGE FERNÁNDEZ (Dir.), La sustracción internacional de menores ..., ob. cit., pp. 193-244, esp. pp. 215-219.

${ }^{37}$ Se ha llegado a firmar que nada sirve de forma más apropiada al interés superior del menor que la tramitación expeditiva de los casos de restitución ( $c f r$. F.J. ForCADA-Miranda, "El nuevo proceso español de restitución o retorno de menores en los supuestos de sustracción internacional: La decidida apuesta por la celeridad y la novedosa Circular de la Fiscalía 6/2015 (Parte I)", Bitácora Millennium DIPr, Num $3^{\circ}$ (enero-junio 2016), pp. 1-15, en esp. p. 10.

${ }^{38}$ Lo que ha generado críticas por parte de cierta doctrina, por cuanto que la aplicación estandarizada de este criterio -sin análisis singular de las circunstancias en cada caso concreto- pondría en peligro la tan deseada justicia material para el caso concreto. En este sentido, puede verse, s. Álvarez GonzÁlez, "Interés del menor y cooperación jurídica internacional en materia de desplazamiento internacional de menores: los casos difíciles", Cooperación jurídica internacional, Colección Escuela Diplomática, núm. 5, Madrid, 2001, pp. 125-136. Lo que en el asunto de referencia no parece que sea el caso, por cuanto que no hay conocimiento de circunstancias vinculadas al progenitor que solicita el retorno o concurrentes en el Estado de origen, que permitieran plantear el recurso al interés del menor para condicionar la devolución de este, más allá de la eventual consideración, subjetiva, de que estuviera integrado en el nuevo medio.

39 Vid., "Informe sobre el Convenio" de E. PÉREZ VERA, loc. cit., núm. 23
} 
o menos discutibles sobre su persona- una de las manifestaciones más objetivas de lo que constituye el interés del menor ${ }^{40}$; dado que la verdadera víctima de la sustracción es el niño ${ }^{41}$.

Por tanto, los objetivos del Convenio responden, en definitiva y en su conjunto, al interés superior del menor. Ahora bien, sin desconocer que es posible que el traslado del menor esté justificado por razones objetivas vinculadas a su persona o con el entorno próximo, lo que tiene reflejo en el instrumento a través de las excepciones del art. 13. En consecuencia, el Convenio reglamenta ciertas excepciones a la obligación general asumida por los Estados contratantes de garantizar de forma inmediata y automática el retorno de los menores trasladados o retenidos ilícitamente ${ }^{42}$.

18. La salvaguarda del interés del menor en el Convenio de la Haya de 1980 exige una aplicación automática de la devolución del menor, salvo que se verifique y se pruebe fehacientemente la concurrencia de alguna de las causas de denegación del art. 13 para el caso concreto (siendo las causas $1 \mathrm{~b}$ y 2 del art. 13 las que materializan los supuestos en los que por el interés del menor se justifica el no retorno para garantizar su tutela). En estos casos (del art. 13), el interés del menor a no ser desplazado de su residencia habitual (Estado de origen), incluso sin garantías suficientes de que la nueva será estable, cede ante el interés primario de cualquier persona -no solo menores- a no ser expuesta a un peligro físico o psíquico, o colocada en una situación intolerable ${ }^{43}$. De esta suerte, de los objetivos y finalidades del instrumento plasmados en su articulado no cabe deducir que haya que verificarse, para cada caso concreto, la satisfacción del interés personal, singular y subjetivo del menor desplazado para resolver automáticamente sobre la devolución inmediata como regla general (pues nada se dice al respecto en el art. 12) y, en consecuencia, tampoco en el asunto de referencia (en la medida que no concurre excepción tasada a esta regla general de las previstas en el art. 13). Por ello, la apreciación del tribunal en apelación de que el interés superior del menor en el caso concreto justifica el fallo de no restitución, carece de fundamentación en la norma convencional en el sentido esgrimido por el juzgador.

19. No puede obviarse el debate doctrinal que ha surgido en los últimos tiempos, a raíz de determinados pronunciamientos del $\mathrm{TEDH}^{44}$, en torno a la necesidad de un mayor análisis del fondo que

${ }^{40}$ El menor como titular del derecho. En este línea se manifestó en su momento la Asamblea Parlamentaria del Consejo de Europa en se Recomendación 874 (1979) (sobre una Carta Europea de los Derechos de la Infancia) cuyo primer principio general señala que "los menores ya no deben ser considerados propiedad de sus padres, sino que deben ser reconocidos como individuos con derechos y necesidades propios". Vid. Asamblea Parlamentaria del Consejo de Europa. $31^{a}$ Sesión ordinaria. Recomendación relativa a una Carta Europea de los derechos del niño. Texto adoptado el 4 de octubre de 1979.

${ }^{41}$ En este sentido se manifestaba el Informe sobre el anteproyecto del Convenio de la Haya, "Questionnaire et Rapport sur l'enlèvement international d'un enfant par un de ses parents", elaborado por D. ADAIR DyER, Doc. Prel. N1 1, agosto de 1977, p. 18-25, en esp. p. 21.

${ }^{42}$ En la mayoría de los casos, tales excepciones no son más que manifestaciones concretas del principio genérico y demasiado impreciso que proclama que el interés del menor es el criterio de base en la materia. El problema del uso de un criterio como este, que es un concepto jurídico indeterminado, para dar respuestas a este tipo de cuestiones es la inseguridad jurídica, dado que su concreción depende de percepciones subjetivas (si bien, permite una solución más adaptada al caso concreto). El peligro que puede constatarse es que este criterio se convierta en una idea intuitiva, que en muchas ocasiones sirve para justificar la solución que parece "justa" en el caso concreto, en lugar de mostrar su exacto valor jurídico. En esta línea, $C f r$. Ma.P. García Rubio, “Aproximación al significado, contenido y alcance del interés del menor” en S. Álvarez GonzÁlez, R. ArenaS García, P. A. de Miguel Asensio, S. Sánchez Lorenzo y G. Stampa Casas (eds.), Relaciones transfronterizas, globalización y derecho. Homenaje al Prof. Dr. José Carlos Fernández Rozas, Thomson Reuters-Civitas, Navarra, 2020, pp. 1075-1090.

${ }^{43}$ Esta aproximación puede verse en el Informe de E. PÉREZ VERA sobre el Convenio (loc. cit.). En concreto en el número 29 expresamente refiere que "los apartados 1 b y 2 del mismo artículo 13 consagran excepciones que claramente se basan en la toma en consideración del interés del menor", y que suponen una excepción al interés del menor que se concreta en la devolución inmediata a su medio habitual (al Estado de residencia habitual de origen) que claudica ante el interés primario de cualquier persona a ser protegida y no expuesta a situaciones de peligro.

${ }^{44}$ Para evitar eventuales infracciones de derechos humanos vinculados al menor, principalmente el derecho a la intimidad familiar del art. $8 \mathrm{CEDH}$ con la ejecución de las órdenes de retorno al Estado de origen en determinadas circunstancias. Entre otras, los asuntos Neulinger y Shuruk v. Suiza (Gran Sala, $n^{\circ}$ 41615/07, sentencia de 6 de julio de 2010, Referencia INCADAT: HC/E 1323) y Raban v. Rumanía (n ${ }^{\circ} 25437 / 08$, sentencia de 26 de octubre de 2010, referencia INDACAT: HC/E/RO 1330), doctrina posteriormente corregida interpretativamente en cierta medida por la sentencia de Gran Sala de fecha 26 de noviembre de 2013, en el caso $X v$. Letonia ( $\mathrm{n}^{\circ}$ 27853/09, referencia INDACAT: HC/E/LV 1234) donde se introdujeron importantes matices conciliadores entre los eventuales intereses contrapuestos (los del menor, los de los progenitores y los de orden público). 
permita evaluar en profundidad cuál sea el mejor interés del menor sustraído en cada caso -más allá del neto factor de la mera devolución automática e inmediata al Estado de origen-, para que se dé así respuesta a esta compleja realidad ${ }^{45}$ de manera garantista de los derechos fundamentales de los menores ${ }^{46}$. Ahora bien, el interés superior del menor es un paraguas muy amplio e indeterminado que es necesario concretar según el escenario ante el que nos encontramos, tal y como proclama Tribunal de Estrasburgo. Así, en el caso $X v$. Letonia, el Tribunal concluye que el interés superior del niño no se puede entender de la misma forma según si el juez debe examinar una demanda de restitución en virtud del Convenio de La Haya, o si debe pronunciarse sobre cuestiones de fondo en una demanda sobre custodia o autoridad parental; concretando que ese interés se relaciona en el Convenio de La Haya con el restablecimiento del statu quo del menor. Así pues, en el marco de un procedimiento de restitución en virtud del Convenio de La Haya, el interés superior del niño se debe evaluar a la luz de las excepciones contempladas en el Convenio. A mayor abundamiento, respecto del papel del Tribunal de Estrasburgo en este tipo de supuestos -procedimientos de retorno ante casos de sustracción internacional de menores-, esta sentencia resulta meridiana, por cuanto que el TEDH no puede sustituir la evaluación de los tribunales nacionales con su propio examen ${ }^{47}$. Ahora bien, debe asegurarse que los procesos decisorios de los tribunales nacionales que los llevan a adoptar las medidas en esta materia -que pueden resultar impugnadas- sean equitativos, permitan a los interesados hacer valer sus derechos plenamente y respeten el interés superior del niño. Asimismo, no hay que olvidar que los derechos fundamentales del menor ${ }^{48}$-y de otras partes implicadas ${ }^{49}$ - también pueden verse conculcados si por el Estado de traslado o retención no se acuerdan las medidas necesarias para hacer efectiva la restitución -a la mayor brevedad posible- en el marco del Convenio de la Haya, como así se ha manifestado el TEDH.

20. Eventualmente, en este contexto incluso también cabría considerar que a través del art. $20^{50}$ del Convenio se abriría la vía al principio superior del menor como causa de denegación de la obligación de la restitución del art. $12^{51}$. Una aproximación de la materia en relación con los derechos fundamen-

${ }^{45}$ Esta aproximación se manifestado no solo respecto del Convenio de la Haya de 1980 sino incluso en relación con el Reglamento Bruselas II bis, planteándose si retornos expeditivos y cuasi automáticos de menores, como los que promulga este Reglamento -procesos urgentes y sumarios-, no conllevaría de hecho indudables vulneraciones de los derechos humanos. Vid. F.J. ForCada-Miranda, “El nuevo proceso español de restitución...”, loc. cit., p. 8.

${ }^{46}$ Lo que por otro lado ya está previsto en el art. 20 del Convenio de la Haya como causa de denegación, que legitima el incumplimiento de la obligación de la restitución automática del art. 12, cuando dicho cumplimiento no lo permitan los principios fundamentales del Estado requerido en materia de protección de los derechos humanos y de las libertades fundamentales (esto es, cuando lo impida en definitiva el orden público del Estado requerido, en el que se integran los derecho y libertades fundamentales).

${ }^{47}$ Como parecía deducirse del párrafo 139 de la sentencia Neulinger and Shurukv. Switzerland (loc. cit.). Precisamente un análisis crítico de esta sentencia desde la perspectiva del papel del TEDH en la interpretación y aplicación de este instrumento puede verse en M. Celis Aguilar, "El papel controversial del TEDH en la interpretación del Convenio de La Haya del 25 de octubre de 1980 sobre los Aspectos Civiles de la Sustracción Internacional de Menores: Especial referencia a los casos Neulinger y Shuruk c. Suiza y X c. Letonia”, ACDI (Anuario Colombiano de Derecho Internacional), vol. 13, 2020, pp. 209-249.

${ }^{48}$ En este sentido, la STEDH de 25 de enero de 2000, en el asunto Ignaccolo-Zenide v. Rumania $\left(\mathrm{n}^{\circ} 31679 / 96\right.$, referencia INDACAT: HC/E/RO 336) por la que se condenó a Rumania por violación del artículo 8 del CEDH, al no haber adoptado las medidas razonablemente exigibles para hacer cumplir una resolución de retorno dictada en el contexto del Convenio de La Haya de 1980.

${ }^{49}$ No solo se ven afectados los derechos fundamentales de los menores en caso de inobservancia de las obligaciones impuestas por el Convenio por los Estados parte, por cuanto que estas se presuponen por el progenitor demandante de la restitución y conlleva que se vea desprovisto de la necesaria protección y, por tanto, que se vea vulnerado su derecho a la vida familiar del art. 8 CEDH. Precisamente a esta conclusión llega el TEDH en su sentencia de 28 de abril de 2015, asunto Ferrari c. Rumania ( $\mathrm{n}^{\circ}$ 1714/10, referencia INDACAT: HC/E/RO 1354); y en la sentencia de 1 de julio de 2014, asunto Blaga c. Rumania $\left(n^{\circ} 54443 / 10\right.$, referencia INDACAT), si bien por decisión mayoritaria (con opinión disidente del Juez López Guerra, a quien se sumó el juez Motoc), el TEDH determinó que había habido una violación del art. 8 de la CEDH y, por unanimidad, que se ha producido una violación del art. 6 del CEDH (por las dilaciones sufridas en el procedimiento de más de 5 años).

${ }^{50}$ Que permite a la autoridad nacional competente denegar la devolución del menor cuando la restitución fuera contraria a los principios fundamentales del Estado requerido en materia de protección de los derechos humanos y de las libertades fundamentales.

${ }^{51}$ Vid. "Informe Explicativo" de E. Pérez Vera (loc. cit.) número 33. En relación con este motivo de denegación de devolución del menor, y las cuestiones de aplicación en el caso de Estados parte plurilegislativos de base personal, puede verse 
tales consagrados en nuestra Carta Magna ha supuesto que el TC haya tenido que fiscalizar el tema a la luz de los derechos fundamentales de protección de la vida familiar (art. $18 \mathrm{CE}$ ), del libre desarrollo de la personalidad (art. $10 \mathrm{CE}$ ), la protección del interés superior del niño (del art. $39 \mathrm{CE}$ ) o de la tutela judicial efectiva (24 CE).

De entre ellas, cabe destacar la Sentencia (Sala segunda) del TC $n^{\circ} 16 / 2016$, de 1 de febrero de $2016^{52}$, de la que cabría deducir que en términos generales el interés superior del menor estaría por encima de cualquier otro interés en pugna en litigios en los que se encuentren menores implicados ${ }^{53}$, incluyendo supuestos de sustracción internacional. Esta resolución surgió a raíz del recurso de amparo presentado por una mujer frente a Auto de la Audiencia Provincial de Madrid ${ }^{54}$ que la obligaba a entregar a su hija de 5 años a su exmarido y padre de la niña (de nacionalidad suiza y residente en aquel país), como resultado de la demanda de restitución incoada, en tiempo y forma, en el marco del Convenio de la Haya de 1980 con base en su art. 12 -sin tener por tanto en cuenta si la menor estaba o no integrada ya en España-. En este asunto el TC entró a valorar la posible vulneración del derecho a la tutela judicial efectiva sin indefensión (art. 24.1 CE) alegada por la madre, que consideraba que había existido falta de motivación en el Auto que se recurre en amparo por varios motivos, a saber: contradicción con otras resoluciones judiciales; falta de ponderación de la situación actual de la menor a la hora de valorar el interés superior de la misma, y discrepancia, a los efectos de determinar la concurrencia del motivo de denegación del retorno del art. 13.b) del Convenio de La Haya de 1980, a la hora de valorar la denuncia interpuesta por la madre por violencia doméstica ${ }^{55}$. Para valorar la adecuación constitucional del Auto recurrido (de su motivación), el Tribunal Constitucional recuerda que la fundamentación de las resoluciones se considera lesiva si en la resolución se observa una absoluta falta de ponderación del principio del interés superior del menor ${ }^{56}$.

Así, el principio del interés superior del menor se traduce en concretas obligaciones para los órganos judiciales -y consecuentemente para poder pasar el control de constitucionalidad-: a) están obligados a llevar a cabo un juicio de ponderación de los intereses en presencia, b) dicho juicio ha de constar expresamente en la resolución, y c) han de identificarse los bienes y derechos concurrentes, que afectan a las distintas partes implicadas, para así poder realizar una valoración de la medida que se adopte, en el sentido de si resulta necesaria y proporcionada. En el asunto analizado, para el TC el análisis del juicio de ponderación en relación con el interés superior del menor del Auto de la Audiencia pasaría por verificar dos cuestiones: por un lado, si se han tomado en consideración las circunstancias actuales del menor, a la hora de ponderar su interés superior para detener la restitución inmediata al país de origen y, por otro, la concurrencia del motivo de denegación del art. 13.b) del Convenio ${ }^{57}$.

En lo que respecta a la primera de las cuestiones ${ }^{58}$, el TC afirma que la integración del menor "constituye un elemento de ponderación imprescindible en relación con el objeto y fin del Convenio y de conformidad con sus previsiones, por lo que su valoración es esencial, cuando se trata del procedimiento

H. VAN LOON, "The accommodation of religious laws in cross-border situations: the contribution of the Hague Conference on Private International Law", CDT (Marzo 2010), Vol. 2, No 1, pp. 261-267, en esp. p.262; C. M. CAAmiÑa Domínguez, "El secuestro internacional de menores: soluciones entre España y Marruecos", Cuadernos de Derecho Transnacional CDT (Marzo 2011), Vol. 3, No 1, pp. 47-62, en esp. p. 56.

${ }^{52}$ Recurso de amparo no 2937/2015, (RTCl2016\16). BOE núm. 57, de 7 de marzo de 2016, páginas 18444 a 18459.

${ }^{53}$ Este interés ha de presidir la decisión a tomar por los jueces, debiendo ponderarlo con el interés de los progenitores, ya que, si bien éste es de menor rango, no ha de ser menospreciado $\left(\mathrm{FJ} 6^{\circ}\right)$.

${ }^{54}$ Sección Vigésima Segunda, de 31 de marzo de 2015. Auto que aclara que el objeto de la apelación es el Auto del Juzgado de 14 de abril de 2014 que resuelve exclusivamente desestimar la solicitud de retorno de la menor, sin acordar pronunciamiento sobre jurisdicción y competencia y confirma de forma motivada la competencia del Juzgado de Violencia núm. 11 de Madrid.

${ }^{55}$ Un análisis crítico de esta sentencia, junto con el ATC119/2015 de 6 de julio, puede verse en F.J. ForCADA Miranda, "Carencias, necesidades y conflictos de la sustracción internacional de menores y el novedoso marco legal español”, REDI, Vol. 68, No. 2 (JULIO-DICIEMBRE 2016), pp. 337-346.

${ }^{56} \mathrm{Vid}$. STC 16/2016, FJ 6 ${ }^{\circ}$, en el que se remite a la STC (Sala Segunda) de 8 de septiembre de 2014 (RTC 2014\138).

${ }^{57}$ Un análisis exhaustivo de esta sentencia, con especial dedicación a la integración del menor como manifestación del interés superior en el asunto de referencia, y en general en la jurisprudencia del TC, puede verse en C. M. CAAMIÑa DomínGUEZ, "El interés superior del menor: la integración en el nuevo medio", CDT, Vol. 8, No 2 (2016), pp. 77-91.

${ }^{58}$ En la que nos vamos a centrar, por ser este aspecto el relevante a los efectos de concluir la adecuación de la sentencia principal objeto de estudio. 
de inmediata restitución" (FJ $10^{\circ}$ ). Si bien, a la luz de este Convenio la integración del menor solo se toma en con sideración si ha transcurrido el plazo del año señalado en el párrafo primero del art. 12, cosa que en este asunto no correspondía con los hechos, pues la restitución se solicitó por el padre en el plazo de 3 meses. Aun así, el TC, en consideración al plazo total transcurrido desde el traslado hasta la resolución del asunto -con independencia de las causas que provocaron el lapso temporal de los veinte meses-, entiende que, en consideración el interés superior de la menor, debía ser valorada la situación actual del niño, puesto que puede haberse producido una plena integración de la menor en su nuevo medio. Así pues, la Sala Segunda del TC decide anular el Auto que ordenaba la devolución de la niña (en segunda instancia) argumentando que sus circunstancias no fueron tenidas en cuenta y que el interés superior de la menor obligaba a valorar su integración en España y que, por tiempo transcurrido, cabría concluir que ya estaba integrada en el nuevo entorno. Concluyendo, en consecuencia, que la resolución objeto de amparo incurre en defectos de motivación que se traducen en la vulneración del derecho a la tutela judicial efectiva sin indefensión de la recurrente ${ }^{59}$.

Las circunstancias concurrentes en este asunto son muy significativas a los efectos de analizar el resultado del TC -que no es extrapolable al supuesto de hecho objeto de estudio-. No solo se produjo dilatación del procedimiento de restitución por cuestiones de competencia objetiva entre los juzgados de primera instancia y de violencia ${ }^{60}$, vinculado al hecho de la existencia de denuncias de malos tratos de la madre frente a su expareja, tanto en España como en Suiza ${ }^{61}$ (siendo que los autos resolviendo sobre competencia fueron recurridos por el padre en segundo instancia); sino que el procedimiento de sustracción internacional de menores (seguido finalmente ante el Juzgado de Violencia contra la Mujer núm. 11 de Madrid) se encuadraba en un entramado de procedimientos subsiguientes a la sustracción (tanto de orden civil como penal). Solo en el orden civil, ante los tribunales suizos se tramitaron dos procedimientos que otorgaban la guarda y custodia de la menor al padre ${ }^{62}$; y ante los tribunales españoles, un procedimiento de medidas paternofiliales ${ }^{63}$ (ante el mismo Juzgado de Violencia que conoce de la restitución), con medidas provisionales previas sobre la menor ${ }^{64}$ (que mediante Auto de 15 de abril de 2014, de forma provisional, atribuía la guarda y custodia a la madre, la patria potestad a ambos progenitores y un régimen de visitas para el padre y obligación de alimentos, así como prohíbe la salida del territorio nacional de la menor sin consentimiento expreso de ambos progenitores o, en su defecto, sin autorización judicial). Las resoluciones suizas que otorgaban la custodia al padre tratan de ser reconocidas infructuosamente ${ }^{65}$ en España mediante exequatur ${ }^{66}$.

Además, el hecho de que el padre estuviera imputado por un delito de violencia de género contra la madre -aunque no se hubiera acordado orden de protección en España y previo sobreseimiento

${ }^{59}$ Se vincula, además, esta conclusión con el cumplimiento de las exigencias derivadas del derecho al respeto a la vida privada y familiar del menor (art. $8 \mathrm{CEDH}$ ) en los términos expresados en la jurisprudencia del Tribunal Europeo de Derechos Humanos, en cuanto obliga a los órganos judiciales nacionales a expresar una decisión suficientemente motivada que refleje un examen eficaz de las causas alegadas como excepción al retorno del menor $\left(\mathrm{FJ} 10^{\circ}\right)$.

${ }^{60} \mathrm{El}$ procedimiento en primera instancia sufrió varias dilaciones debido a cuestiones de competencia objetiva entre el juzgado de primera instancia y el de Violencia de género. Los Autos de instancia sobre la competencia son también recurridos en apelación (solicitando su nulidad), junto con el pronunciamiento sobre la denegación de restitución del menor -que es finalmente sobre lo que resuelve la Audiencia Provincial, vid supra nota 47).

${ }^{61}$ Por hechos supuestamente cometidos en España, Suiza y Grecia. Aunque las denuncias por violencia entre los progenitores eran cruzadas.

${ }^{62}$ Procedimiento de medidas previas super provisionales, resuelto por providencia del Tribunal Regional de las Montañas y Val-de Ruz de 12 de septiembre de 2013, y de medidas provisionales, resuelto por Auto del mismo órgano judicial de 11 de diciembre de 2013, confirmada por resolución del Tribunal Cantonal de Neuchâtel de 10 de febrero de 2014 y finalmente por Sentencia del Tribunal Federal de Laussanne, de 25 de junio de 2014

${ }^{63}$ Autos de guarda y custodia 5-2014) en el que la demanda fue admitida a trámite por Decreto del Juzgado de 26 de junio de 2014

${ }^{64}$ Demanda de medidas provisionales previas 1-2014. En el curso de las medidas provisionales previas se desestimó una declinatoria de jurisdicción planteada por el padre mediante el Auto de 3 de marzo de 2014, confirmado por Auto de 2 de junio de 2014.

${ }^{65}$ La solicitud fue desestimada por Auto de 23 de junio de 2014.

${ }^{66}$ Solicitado ante el Juzgado de Primera Instancia núm. 29 de Madrid. Autos 911-2013. 
provisional de la causa penal incoada ${ }^{67}$ - justifica que el Auto del Juzgado de violencia que conoce de la restitución fundamente la denegación de la restitución del menor con base en el art. 13 letra b del Convenio de la Haya; circunstancia que fue desestimada por la Audiencia Provincial de Madrid, al resolver sobre la restitución en segunda instancia considerando no probado el peligro respecto del menor -sino en relación con la madre-, reproduciendo el art. 12 del Convenio de la Haya para acordar la devolución. En este contexto, con todos estos factores concurrentes, el TC considera que la resolución recurrida adolece de la motivación debida en los términos ya expuestos.

21. En el caso de referencia no existen factores externos particulares que pudieran exigir que, con base en el interés superior del menor, el tribunal nacional que debe resolver sobre la devolución (la Audiencia Provincial en apelación) haga un mayor análisis de fondo para justificar la excepción a la regla general ( $v$. gr. antecedentes de violencia doméstica, dejación en el ejercicio de los deberes paternofiliales, oposición expresa del menor, etc.). Pues según se desprende de los autos, la razón que esgrime la Audiencia para entrar a valorar la integración del menor en el España es que se está ante un supuesto del segundo párrafo del art. 12, por haber transcurrido el plazo del año, cuando el cómputo no se ha realizado correctamente como ya se ha expuesto. Por ello, el recurso al principio del interés superior del menor para denegar la restitución, no procediendo la excepción del segundo párrafo del citado precepto, solo correspondería cuando se verificaran de forma fehaciente alguna de las causas de oposición a la devolución del art. 13 -que en el caso objeto de análisis no se han referido ni en primera ni en segunda instancia- o en caso del art. 20 (que tampoco procede su apreciación en el asunto de referencia).

El mero transcurso del tiempo desde que se produce el traslado ilícito hasta la resolución del procedimiento (cuando la restitución fue solicitada en tiempo y forma por el legitimado), en sí mismo considerado, no puede ser la base para introducir la valoración de la integración en el nuevo medio de forma automática, a través del recurso al principio genérico del interés superior del menor, para oponerse y denegar la devolución. Más aún cuando se verifica el incumplimiento en los plazos establecidos en la legislación procesal nacional para resolver este tipo de procedimientos por la autoridad judicial competente (incumpliendo así mismo la "urgencia" que reclama e impone el Convenio de la Haya ${ }^{68}$ ). La posible dilatación del procedimiento en sede judicial, en sus distintas fases (incluidos recursos en otras instancias), es un factor que no depende de las partes y que su consideración sin más argumentos, basados en elementos fácticos objetivos y específicos del caso concreto ${ }^{69}$ (que permitieran fundamentar una excepción a la obligación de devolución automática), supondría inclinar la balanza injustificadamente a favor del progenitor que ha sustraído ilícitamente al menor en detrimento de los derechos fundamentales del progenitor que ha actuado correctamente (siguiendo las instrucciones normativas, con expectativas legítimas para ver satisfecha su solicitud); en mayor medida en aquellos casos en los que la ley nacional permita recurrir a artimañas procesales por las partes para dilatar los procedimientos. En este sentido, se crearía un precedente peligroso -una especie de fórum shopping-, en la medida que con acudir a aquellas jurisdicciones más "lentas" en la resolución de los asuntos (o incluso dentro de una misma jurisdicción nacional, a aquellos partidos judiciales con "mayor atasco") el recurso al interés superior del menor justificaría la valoración de la integración del menor por el tiempo transcurrido hasta la resolución (agotando todas las instancias); lo que dependiendo de la edad del niño puede ser una cuestión casi automática de denegación u oposición a su retorno.

${ }^{67} \mathrm{Si}$ bien, posteriormente procedida la reapertura de las actuaciones en Auto de 27 de noviembre de 2013, pendiente de resolución a fecha de resolución del recurso de amparo.

${ }^{68}$ De conformidad con sus artículos 2 y 11.

${ }^{69}$ Que es en definitiva extrapolar lo que se reclama por la doctrina que se manifiesta favorable a un análisis específico y particular del mejor interés del menor en los casos de sustracción de menores y no a una aplicación de este criterio automática en la que se identifique dicho interés a la devolución inmediata sin más revisión de las circunstancias concurrentes; típicamente en relación a supuestos vinculados a casos de violencia de género, dejación del ejercicio de funciones, u otros factores que repercuten negativamente sobre el menor -no como en el asunto de referencia-. En este sentido, puede verse, J. FERNÁNDEZ NIETO, "Sustracción internacional de menores e indisponibilidad del principio universal «interés superior del menor» en los procesos de violencia de género y custodia: los verdaderos obstáculos en la armonización del derecho de familia europeo", La ley penal: revista de derecho penal, procesal y penitenciario, $\mathrm{N}^{\circ}$. 130, 2018. 
No obstante, no cabe duda de que sea o no imputable a las partes el transcurso del tiempo, esto incide en la eventual apreciación de la integración del menor en el nuevo entorno -en interés de éste-. Dependiendo de la edad con la que cuente el niño y la extensión del plazo transcurrido -en atención a las circunstancias particulares ${ }^{70}$ - todo ello puede ser determinante para considerar que un nuevo cambio sea más perjudicial que beneficioso para el menor. Ahora bien, en cualquier caso, no puede entenderse que esta apreciación sea, fuera de las excepciones marcadas por el Convenio, labor de la autoridad que debe de resolver sobre la restitución, sino que debe apreciarse por la jurisdicción que tenga competencia para conocer sobre el fondo ${ }^{71}$ : el derecho de guarda y custodia (ejercicio/atribución).

\section{Conclusiones: el Convenio de la Haya como una asignatura pendiente en la práctica nacional.}

22. Las limitaciones del juzgador -en cuanto a los elementos de valoración- en el procedimiento sobre retorno del menor ante un supuesto de sustracción internacional en el marco del Convenio de la Haya de 1980 son evidentes, según se desprende del propio texto. El sistema del Convenio deja conscientemente al margen los aspectos relativos al fondo, esto es, la guarda y custodia del menor (su atribución, el ejercicio o su organización, tanto en lo que se refiere a la previa a la sustracción como a la posterior tras la devolución).

El pronunciamiento que los tribunales del Estado contratante de retención o traslado ilícito del menor dicte, en aplicación del instrumento, se debe limitar estrictamente a resolver si procede o no la devolución del menor al país en donde residía habitualmente. En caso de que se acuerde la restitución, serán las autoridades competentes del país de origen las que, en su caso, decidan sobre la custodia del menor -y cualesquiera otras cuestiones relativas a la responsabilidad parental sobre el menor-, solo en caso de que el retorno sea denegado, el tribunal del foro podrá entrar a conocer sobre el fondo como Estado de nueva residencia habitual del niño. Como consecuencia de esto, no puede pronunciarse sobre el fondo del asunto, sobre las cuestiones relativas a la responsabilidad parental a las que típicamente se vincula la sustracción, ni valorarse por la autoridad judicial del Estado de ubicación física del menor (en el caso de referencia, por los tribunales españoles) cuál es la situación de los menores para decidir con cuál de los progenitores deben convivir. La autoridad judicial debe limitarse a verificar si concurren o no las condiciones marcadas por el Convenio para proceder a la devolución del menor -o denegarla- sin entrar en el fondo del asunto, es decir, en la atribución /ejercicio del derecho de custodia en pugna, que en principio tendrá que ser el debatido y resuelto en el Estado de origen por ser la residencia habitual del menor (salvo que se adquiera la consideración de nueva residencia del menor).

En caso contrario, si el tribunal del foro apreciara circunstancias o elementos de valoración ajenos a las condiciones marcadas en el Convenio para fundamentar su resolución, esto es, si buscara causas o factores no previstos ni referidos en el instrumento para resolver sobre la devolución (más allá de la causas de oposición de los arts. 13 y 20 y la excepción del párrafo segundo del art. 12), se estaría vulnerando la finalidad de la norma. El principal objetivo que fundamenta y justifica su existencia, no es otro que garantizar la inmediata devolución del menor al Estado de origen, es decir, al de su residencia habitual antes de ser trasladado o retenido ilícitamente a otro Estado contratante -y ello pese a que su cumplimento pueda resultar eventualmente perjudicial para el menor en un futuro ${ }^{72}$.

\footnotetext{
${ }^{70}$ Un ambiente familiar, social y cultural del nuevo entorno que permita garantizar el correcto desarrollo del menor (en el plano físico y psicológico), de modo que su permanencia en el nuevo país resulte más ventajosa que su devolución al Estado de origen.

${ }^{71}$ En esta línea, C. M. CAAmiña Domínguez, "El interés superior del menor...”, loc. cit., p. 91.

${ }^{72}$ En este sentido, se ha manifestado cierta doctrina afirmando que el cumplimiento de las obligaciones internacionales derivadas de esta norma podría implicar la vulneración de los intereses de los menores si llegara a suponer a corto o largo plazo consecuencias perjudiciales para el menor. $C f r$. G. MOREno CORDERo, "Las medidas de protección como garantía para un retorno seguro del menor sustraído o retenido ilícitamente: tensiones entre el grave riesgo y el interés superior del menor" en Ma . C. García Garnica / N. Marchal Escalona (dirs.), Aproximación interdisciplinar a los retos actuales de protección de la infancia dentro y fuera de la familia, Thomson Reuters Aranzadi, Navarra, 2019, pp. 607-635, en esp. p. 632.
} 
23. El cómputo del plazo que rige la regla general del art. 12, que obliga a los Estados contratantes a la devolución automática del menor si no ha transcurrido un año desde que se produjo el traslado o retención ilícito, plantea en la práctica distintas cuestiones interpretativas no uniformizadas para los Estados contratantes (más allá de las precisiones sobre la extensión del plazo y la finalización del mismo en los informes explicativos), por cuanto que las indicaciones referidas al inicio del cómputo (dies a quo) están abiertas a interpretación discrecional de los hechos por las autoridades competentes para resolver sobre la devolución del menor ${ }^{73}$; lo que condiciona significativamente el resultado del procedimiento de restitución (de lo que da muestra la sentencia objeto de análisis).

En el caso de referencia no puede desconocerse que el padre solicitó la restitución en tiempo, esto es, antes del transcurso del año desde que se produjo el traslado ilícito -debiéndose computar como tal cuando el traslado a España pasó de tener carácter temporal, y por tanto autorizado, a ser definitivo-, solicitando de manera casi inmediata a la autoridad central española competente la restitución (dejando al margen la dilación de esta autoridad a la hora de formular demanda en sede judicial a tales efectos, tardando desde julio hasta noviembre de 2019). De esta suerte, el padre debería haber obtenido el retorno automático e inmediato del menor -impuesto en el art. 12 primer párrafo a las autoridades de los Estados contratantes- sin que el juzgador (la Audiencia provincial en resolución del recurso de apelación) pudiera entrar a valorar factor alguno adicional, como es que el menor pudiera estar integrado en el nuevo entorno, por supuesta imposición del interés superior del menor -dado que no concurren las circunstancias del segundo párrafo del art. 12-. Más aún cuando, como ya se ha indicado en parágrafos precedentes, este criterio indeterminado -el interés superior del menor- no aparece referido expresamente en la disposición aplicable, por lo que no puede operar como criterio corrector del objetivo de la norma convencional -tal y como ha sido delimitado en los informes explicativos ${ }^{74}$-. En caso contrario, si se impone una aplicación restrictiva del instrumento haciendo una interpretación de la disposición (art. 12) contraria a la finalidad y objetivos de la norma, con fundamento último en el interés superior del menor, podría suponer una lesión a la tutela judicial efectiva del progenitor (art. 24 CE/art. $6 \mathrm{CEDH}$ ) que solicita restitución en los términos establecidos en el Convenio con legítimas expectativas de éxito.

24. Por último, cabe constatar que tanto en primera como en segunda instancia los tribunales nacionales han aplicado de forma deficiente e incorrecta las medidas procesales previstas por la LEC para el cumplimiento de las obligaciones derivadas para España de este Convenio (si bien, por distintos motivos). Previamente a la modificación de la LEC en este sentido (operada por la LJV), podría concluirse que la aplicación por nuestros tribunales del procedimiento especial consagrado en la norma de 1881, para dar respuesta a los aspectos civiles de la sustracción internacional de menores, conllevaba en términos generales el incumplimiento de la exigencia de la brevedad de los plazos establecidos en el Convenio, e incluso, en última instancia, de proceder al retorno del menor desplazado a España ilícitamente $^{75}$-es más, incluso podía conducir a situaciones claudicantes y, sobre todo, lesivas de derechos

\footnotetext{
${ }^{73} \mathrm{La}$ exploración de potenciales formas normativas, instrumentos o mecanismos que permitieran mejorar la aplicación del Convenio, en particular la posibilidad de articular textos legales obligatorios, como un Convenio o un Protocolo, y el uso de recomendaciones, declaraciones, Leyes modelo, principios generales y guías de buenas prácticas, así de como potenciales handbooks en este contexto se ha puesto de manifiesto de forma reiterada desde la aprobación del texto convencional en la consecutivas reuniones de la Comisión Especial para revisar el funcionamiento práctico de los Convenio de 25 de octubre de 1980 y de 19 de octubre de 1996 de la Conferencia de la Haya, sin resultados concretos por la falta de unanimidad manifestada por los Estados contratantes, más allá de la guías de buenas prácticas publicadas por esta instancia internacional y las conclusiones y recomendaciones de la Comisión Especial sobre el funcionamiento práctico del Convenio de 1980 sobre Sustracción Internacional de Menores y del Convenio de 1996 sobre Protección de Niños a las que llega en sus reuniones periódicas. La doctrina también se ha manifestado en este sentido favorable, en particular, a la conveniencia de adoptar un Protocolo para solventar las deficiencias del texto convencional en los distintos aspectos problemáticos (entre otros, el alcance e interpretación del art. 21 sobre la extensión del procedimiento al derecho de visita, aplicación en relación con las denominadas cláusulas $N e$ Exeat, etc.). A este respecto véase la referencia doctrinal recogida en F.J. ForCADA-MirAndA, "El nuevo proceso español de restitución...", loc. cit., en su nota $\mathrm{n}^{\mathrm{o}} 5$.

${ }^{74}$ Loc. cit. números $20-26$, en esp. núm. 23.

${ }^{75} \mathrm{Vid}$. S. Álvarez GonZÁLEZ, “Desplazamiento internacional de menores...”, loc. cit., pp. 52-56 y jurisprudencia ahí referida.
} 
fundamentales, tales como la tutela judicial efectiva ${ }^{76}$-. Todo ello se ha tratado de superar, al menos en apariencia, con la nueva reglamentación procesal de las medidas relativas a la restitución o retorno de menores en los supuestos de sustracción internacional (Cap. IV Bis LEC). Así, se prevé un procedimiento especial aplicable para la ejecución de un convenio internacional -o las disposiciones de la Unión Europea- que pretenda la restitución de un menor o su retorno al lugar de procedencia por haber sido objeto de un traslado o retención ilícito y se encuentre en España, con plazos de urgencia en las dos fases en las que puede desarrollarse en procedimiento, previendo expresamente que en caso de recurso de apelación éste tendrá efectos suspensivos respecto de la resolución por la que se acuerda la restitución para garantizar los derechos fundamentales de todas las partes (art. 778 quinquies LEC).

La aplicación por las autoridades judicial de las medidas procesales nacionales necesarias para llevar a cabo el proceso de restitución indicado en el Convenio -en tiempo o en infracción de los plazos señalados, como en el caso de referencia-, no deberían incidir en la obligación de restitución automática del art. 12. En particular, para fundamentar eventuales resoluciones de denegación de devolución, como parece que ocurre en la práctica jurisprudencial nacional bajo el paraguas del interés superior del menor, justificando en ello la valoración de la integración del niño en España (en concreto, con base en la jurisprudencia del TEDH en relación con el art. 8 CEDH y de nuestro TC como manifestación del derecho fundamental del art. $39 \mathrm{CE}$ ). Esta aproximación no significa que se desconozca la importancia de valorar la integración del menor en el nuevo medio en cumplimiento del mejor interés del niño. No obstante, fuera de los casos establecidos en el propio Convenio, su apreciación -con las correspondientes consecuencias en la atribución y/o ejercicio del derecho de guarda y custodia- no puede realizarse en el marco de un procedimiento de restitución, sino en todo caso en un procedimiento sobre el fondo del asunto (que generalmente tendrá que sustanciarse ante los tribunales del Estado de origen, por cuanto que conservan su competencia como país de residencia habitual del menor en los casos de sustracción para conocer sobre las acciones relativas a la responsabilidad parental y medidas de protección de los menores ${ }^{77}$ ).

\footnotetext{
${ }^{76}$ A este respecto véase STC 120/2002, de 20 de mayo BOE núm. 146, de 19 de junio de 2002 (ECLI:ES:TC:2002:120), por el que se concede el amparo por la falta de obtención de una decisión judicial sobre el fondo del asunto fundamentada en Derecho, en un caso en el que la Audiencia Provincial de Madrid no resolvió sobre el fondo en un recurso de apelación no suspensivo, formulado por la madre frente a sentencia de primera instancia por la que se declaraba el traslado del menor de Polonia a España como ilícito y se acordaba la restitución inmediata del mismo, por cuanto que dicha restitución fue realizada, y se entendió por el tribunal ad quem que, consecuentemente, el recurso había quedado vacío de contenido. Un análisis pormenorizado de esta sentencia en Vid. S. ÁlvAREZ GonzÁlez, "Desplazamiento internacional de menores...”, loc. cit. Esta cuestión queda superada en la actualidad dados los efectos suspensivos del recurso de apelación formulado frente a la eventual sentencia de retorno que establece el vigente art. 778 quinquies en su numeral 11.

${ }^{77}$ En el caso de referencia, de conformidad con el art. 7 del Convenio de la Haya de 1996.
} 